\title{
Success Factors of Local Retail Apparel Clothing Brands in a Southeast Asian Market
}

\author{
Mostaque Ahmed Zebal ${ }^{1} \&$ Anushe Zebal ${ }^{2}$ \\ ${ }^{1}$ Associate Professor of Sales and Marketing, Andrew F Brimmer College of Business and Information Science, \\ Tuskegee University, USA \\ ${ }^{2}$ Graduate Research \& Teaching Assistant, Auburn University, USA \\ Correspondence: Mostaque Ahmed Zebal, Associate Professor of Sales and Marketing, Andrew F Brimmer \\ College of Business and Information Science, Tuskegee University, 1200 West Montgomery Road, 307 \\ Brimmer Hall, Tuskegee, AL 36088, USA. E-mail: mzebal@tuskegee.edu or mostaque.zebal@yahoo.com
}

Received: June 15, $2020 \quad$ Accepted: August 7, $2020 \quad$ Online Published: August 19, 2020

doi:10.5539/ijms.v12n3p52 URL: https://doi.org/10.5539/ijms.v12n3p52

\begin{abstract}
Purpose - The purpose of the study is to explore and identify the factors that shape the success of local retail apparel clothing brands in a Southeast Asian market, Bangladesh. The study further offers relevant propositions on the basis of the results.

Design/methodology/approach - Focus group methodology was used for data collection from the local retail clothing consumers of Dhaka and Chittagong divisions in Bangladesh. Framework analysis was applied for coding, categorizing, identifying the themes from the audiotapes and transcripts. The focus group transcripts were coded for common themes, issues, or ideas as expressed by the participants. Similar responses were identified from a prepared data matrix on the basis of the most frequent mentioned and less frequently mentioned responses. The research results were presented in a narrative to retain the authenticity of the local dialect and provide insight into the consumer behavior.

Findings - Three critical factors were identified responsible for the success of local retail apparel clothing businesses in Bangladesh. The results revealed that the retail companies were heavily benefited by the adoption of intrinsic/extrinsic factors (product quality, price, and building retailers' reputation and brand name) and culture specific marketing efforts (after sales service, easiness of online transaction, convenient location, store atmosphere, availability of outlet, promoting cultural events, and local celebrity endorsement). The companies were further found advantageous of the socio-economic factors of the country (increase of purchasing power, rapid expansion of tertiary academic institutions, family influence, and change of behavioral pattern).
\end{abstract}

Originality/value - The study enriches the consumer behavior literature related to local retail apparel branded companies and leaves implications to both the mangers and academics.

Keywords: local retail apparel clothing brands, success factors, Southeast Asia, Bangladesh

\section{Introduction}

Consumers in developing countries firmly believe that the product produced in technologically advanced developed countries are superior (Muruganantham \& Priyadharshini, 2017; Netemeyer et al., 2004; Batra et al., 2000; Li et al., 1997). This is because technologically advanced countries produce products with high performance and durability and, often characterize with high brand name, high price, and retailers' reputations. Research on shopping behavior investigated the consumers' reasons to buy and not to buy (Thomas \& Carraher, 2014; Ahmed et al., 2014; Al-Kwifi \& Ahmed, 2014; Mujtaba, 2013). High performance and durability are internal attributes of a product which are fundamental requirements that lead consumer purchase. These are known as intrinsic factors. Further, price, brand name, and retailers' reputation are external product attributes that cause purchase which are known as extrinsic factors (Muruganantham \& Priyadharshini, 2017; Wang \& Chen, 2004; Wang et al., 2000). Literature review reveals that the products produced in developing countries lack intrinsic and extrinsic factors. Thus, the consumers in these countries prefer imported goods produced in technology advanced developed countries (Piron, 2000; Batra et al., 2000; Agbonifoh \& Elimimian, 1999; Li et al., 1997; Kottak, 1990; Herche, 1992). This has become a challenge for the local companies in developing countries which causes poor 
sells and business loss. It is however, not the case for the local retail apparel clothing companies in Bangladesh, a Southeast Asian developing country market. In fact, anecdotal observation suggests that these companies are more successful than their rivals imported goods in terms of business viability. But, why? Have they done something different that they are more successful than imported goods? This is to be investigated.

Consumer behaviors were studied in the area of private label brands where products are manufactured by a third party but sold by a retailer with its own packaging (Batra \& Sinha, 2000; Lin et al., 2009; Chaniotakis et al., 2010). Further studies in developing countries also identified the consumers' preferences on domestic versus foreign products (Batra et al., 2000; Li et al., 1997; Ger et al., 1993; Sklair, 1994). But nothing has been done that investigated the consumer behavior towards the success of locally produced retail apparel clothing brands in Southeast Asia e.g., developing Bangladesh in particular. Hence there is a gap and it is to be investigated. Shopping has long been regarded as a risky activity as shoppers may be uncertain of a purchase decision (Bauer, 1960). This uncertainty does not only hinder purchase but also risk consumption. Thus, it is critical that a company initiate appropriate marketing efforts to unlock answers on what, when, why, where, how, and how much consumers buy and what information they need to buy (Kotler \& Armstrong, 1997). We should keep in mind that consumer's problems are a nation's problems and if left unattended, they become wasted of resources (Margolius, 1982).

\section{Literature Review}

Various factors whether positive or negative influence consumers buying decisions. A positive factor is likely to induce and a negative factor likely to discourage product purchase. Thus, the factors responsible for influencing buying decisions must be perceived very carefully by knocking consumers' head and mind (Kotler, 1997). Purchase of a product has three distinct but interrelated situations; purchase intention, actual purchase, and repeat purchase. Purchase intention indicates that consumers follow their experience, characteristics, preference and, external and internal environmental factors of products to collect information and make purchase decisions (Zeithaml, 1988; Dodds et al., 1991; Schiffman \& Kanuk, 2000). This is a purchase probability that an individual may buy a certain product now or in the future (Whitlark et al., 1993; Halim \& Hameed, 2005; Fandos \& Flavian, 2006). Dodds et al. (1991) viewed this as prioritizing certain products compared to others. Thus, purchase intention depicts the impression of customer retention and is not limited to the pre-purchase stage. Purchase of a product has substantial and significant importance to a company because of its profit maximization potential. Thus, marketers continuously make efforts to enriching customers with inputs to favor their products compared to the competitors.

Consumers in both developed and developing countries normally use intrinsic (performance and durability) and extrinsic factors (price, brand name, and the retailers' reputation) to evaluate products and services (Muruganantham \& Priyadharshini, 2017; Chrysochou et al., 2012; Lee \& Lou, 2011; Neumann \& Henneber, 2007; Enneking et al., 2000; Szybillo \& Jacobya, 1974). Consumers are value conscious and attracted by product quality (Burton et al., 1998; Muruganantham \& Priyadharshini, 2017) which is often translated as performance and durability. Furthermore, consumers tend to pay less and look to save money (Garretson et al., 2002) which ultimately influence purchase decision (Beneke et al., 2013). Brand and store name perceive to influence purchase of a product (Richardson et al., 1994; Bellizzi et al., 1981) due to the risks associated with the product (Wu et al., 2011). Retailer's store image increases store values and attracts customers towards the purchase (Muruganantham \& Priyadharshini, 2017; Martenson, 2007).

Appropriate marketing efforts shape consumers' attitude towards the purchase of locally produced retail clothing brands. For example, advertising spokespersons are driving forces that influence purchase intentions (Laffery \& Goldsmith, 1999) and generate overwhelming consumer response regarding the product (Chen \& Chang, 2001). Further, appropriate use of celebrities contributes to creating, enhancing and changing brand images due to their ability to create positive images to the associated brand (Jansson \& Power, 2010). Marketing efforts using online facilities make it possible to display fashion items more appropriately than traditional stores (Saiki, 2008). This is especially popular among collegiate consumers (Ha et al., 2007). Thus, it is important for any clothing retailers to facilitate online shopping system since virtual experiences enable consumers to understand a product before purchasing it (Yang \& Young, 2009), which also saves money and time for consumers. Furthermore, this online facility enhances fashion garments' sales and builds brand loyalty (McCormick \& Livett, 2012). Customers often choose stores that provide comparatively higher levels of customer service. Store location, knowledgeable salespeople, return provision, and physical evidence are key factors that shape consumers' attitude towards the purchase of locally produced clothing brands. Paulins and Geistfeld (2003) recommended that retailers should set attractive store attributes for their targeted costumers. Michon et al. (2008) document the shopping mall environment as an influencer of the shopping experience and behavior of fashion-oriented, middle-of-the-road 
female consumers. Clarke et al. (2012) revealed that tangible and intangible items such as smell, lighting, sound, and, presence and touch of top management in the store affect consumers' shopping experiences.

Socioeconomic factors are the social and economic experiences and realities that help mold personality, attitude, and lifestyle for individuals and groups in a given society. These factors influence purchase in a given society (Glynn \& Chen, 2009). Social factors involve customs, traditions, values and beliefs that contribute to the growth of the economy of a country. Socioeconomic factors like education and income challenge old stereotypes that shape perceptions of the store brand clientele (Muruganantham \& Priyadharshini, 2017). Economic growth is related to increases in per capita national output or net national product (Nitisha, 2018). Income has become one of the most important socioeconomic parameters that influence consumers' attitude towards own brands (Beneke, 2010; Anchor \& Kourilova, 2009). Bangladesh has witnessed tremendous economic growth over the last few decades (Rahman, 2014). According to World Bank (2018) the economic growth of Bangladesh for 2018 and 2019 was $6.5 \%$, and $6.7 \%$ respectively. The GDP size of the country was $\$ 274.5$ billion for the 2017-2018 fiscal year and $\$ 249$ billion for the previous year (Byron, 2018). Due to the economic growth in this country, it experiences a high employment rate with rising income, improved standard of living, and high consumption of people. This has changed peoples' shopping habits as well as their behavior on the purchase process in recent days. Thus, it is expected that the success of local retail apparel brands in Bangladesh is dependent on socioeconomic factors.

\section{Research Method}

The study used focus group method to capturing the richness and depth of natural conversation through face to face interactions (Thomas et al., 1995). It is a planned discussion group that helps gaining insight into the subject perceptions in a defined filed of interest within a permissive and open format (Krueger, 1994). Furthermore, information gained from focus group improves understanding of a phenomena of interest, consumer behavior research in particular (Dabholkar et al., 1996; Stewart \& Shamdasani, 1990; Parasuraman et al., 1988).

The study conducted three focus group interviews, one from the Port City of Chittagong and two from the Capital City of Dhaka (one from Dhaka North and one from Dhaka South). Each focus group contained six respondents (3 male and 3 female), eighteen respondents in total—aged between eighteen to sixty years. A focus group of six to eight members generally creates the most effective group dynamics and performance (Barbour, 2007). The local retail stores that produce their own brands and sell through their own retail outlets were targeted for data collection for this study. Respondents for the focus groups were spotted in the stores during their shopping and were approached to participate in a consumer behavior related study. They were further informed about the study purpose and what is required to do to ascertain their participation in the study. Selected respondents were further contacted to schedule a focus group sitting. Participants were selected on the criteria that would have something to say on the topic, are within the age-range, share similar socio-characteristics, and would be comfortable to take part in the process (Richardson \& Rabiee, 2001). Each focus group meeting lasted about ninety to one hundred minutes and was administered by three moderators, one principal and two assistants (Carson et al., 2001; Krueger \& Casey, 2000). While the principal moderator was an area expert, who took full responsibility for controlling and moderating the interviews, the assistant moderators were responsible for managing logistics and taking hand notes (Carson et al., 2001; Krueger, 1994). The focus group meetings were audiotaped and conducted in Bangla.

The validity of the data was assessed in line with Goodwin et al. (1997). First, the summary of the findings was sent to three participants (one participant from each focus group) for their comments and suggestions and, all three participants fully agreed with the findings' summary of the study. Second, copies of the draft version of the findings were given to two different marketing academics for comment. Both approved the content of the draft with no negative feedback. The study used framework analysis for coding, categorizing, identifying the themes from the audiotapes and transcripts (Krueger, 1994; Ritchie \& Spencer, 1994). All focus group interviews were fully translated, transcribed, sorted and classified in a systematic and iterative manner widely recommended in the qualitative literature (Ritchie \& Spencer, 1994; Turner, 1981). To identify similar responses in each factor, the focus group transcripts were coded for common themes, issues, or ideas as expressed by the participants (Ritchie \& Spencer, 1994; Reynolds \& Gutman, 1988). A data matrix was prepared by assigning the responses for each participant against each identified factor (Krueger \& Casey, 2000). This matrix helped the researcher to compare answers from one participant to another (Krueger \& Casey, 2000; Martin \& Turner, 1986), as the responses were easy to visualize and interpret. To analyze the transcribed data, similar responses were identified from the data matrix on the basis of the most frequent mentioned responses and less frequently mentioned responses. The research results were presented in a narrative to retain the authenticity of the local dialect and provide insight into the consumer behavior regarding local retail apparel clothing brands in Bangladesh. 


\section{Results}

\subsection{Intrinsic and Extrinsic Factors}

The results of the focus group meetings suggest that quality, price, brand name and retailers' reputation influence the purchase of local retail apparel clothing in Bangladesh which can be viewed in Figure 1.

Quality-The focus group participants suggested that the locally produced retail clothing companies are successful due to their uncompromising behavior towards selling the quality products. Their products are durable, well stitched, and well finished. A female participant from Dhaka responded as follows:

[.....] The finishing of our locally produced clothing is extremely well. They fit in the body very well. Stitching is on top of everything. Very durable. If I buy imported clothing, the stitching is so bad. I need to stitch that again. Above all, our products are very durable [....]. I can use them for many years and they do not lose the originality. Why should I than buy imported clothing? I should buy our own. Isn't it? [.....].

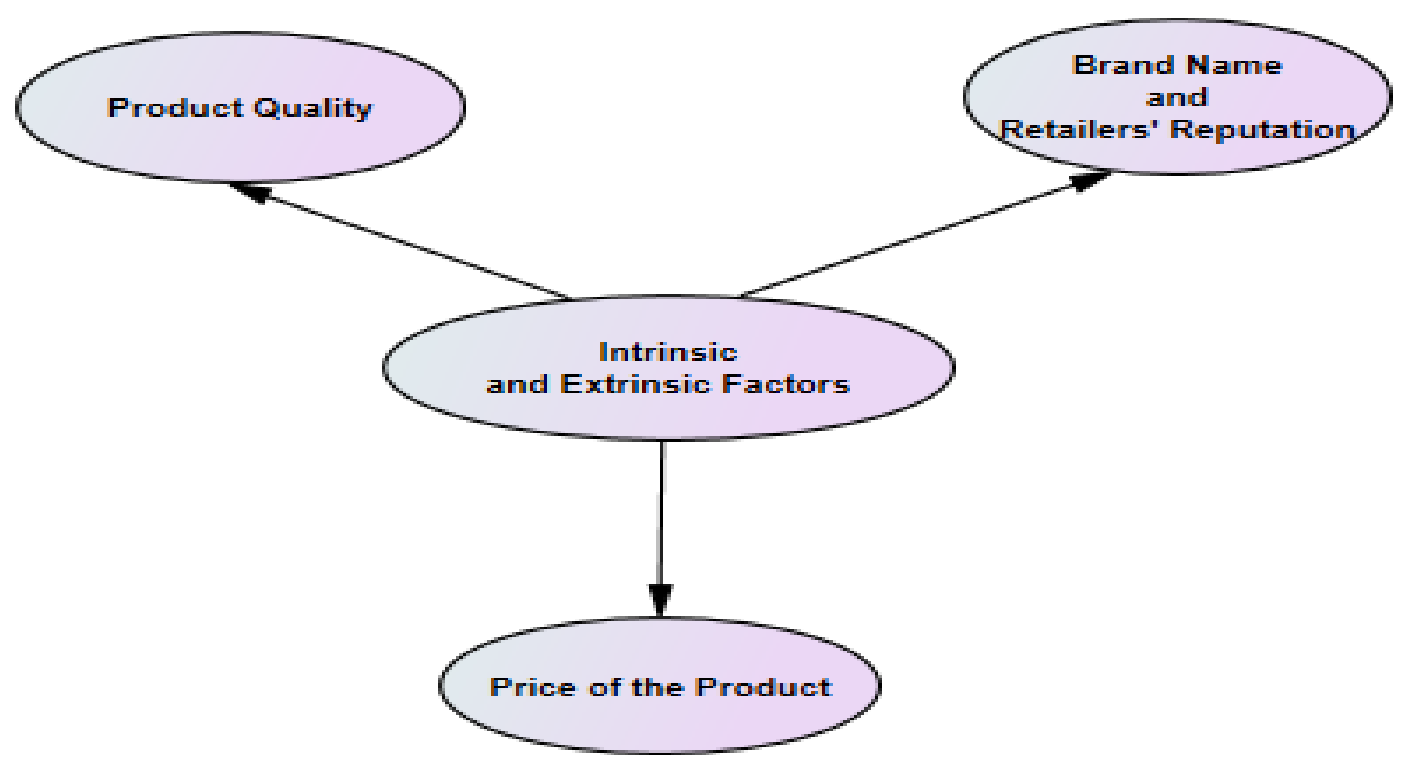

Figure 1. Intrinsic and extrinsic factors

Price-The focus group participants suggested that they buy locally produced retail clothing because these are cheaper compared to the imported foreign brands. A male participant from Chittagong responded as follows:

[.....] If you compare, the price of imported well-known brand is so high and most of our people cannot effort it. In fact, these are beyond of our reach [...... I I can buy three items from local retailers with the same amount of money that I need to spend to buy one foreign item. And the quality is almost same or even better. Why should I then waste my money?

Brand name and retailers' reputation-The results of the focus group meetings revealed that the people in Bangladesh buy from the local retail stores due to the brand name. They thought that the local retail apparel clothing companies could establish themselves as branded companies over the years and so they are more successful in doing business than their counter part imported foreign branded companies. This can be evident by a response of a male participant from Dhaka.

[.....] People buy locally produced clothing because the local retail stores have become brands. Younger and older generation both look for branded items during their purchase. Moreover, if you buy from top most foreign branded stores that are available in Bangladesh, you would find them made in Bangladesh as well. Why would you then buy your own products from a foreign branded store? Further, our retail apparel branded items are much better than the imported brands. Our retailers use the same materials and technologies that of the foreign branded companies but our products are incomparable due to their stitching, finishing, and design [.....]. Have you looked at the color combination and how the garment fits on the 
body? These are unique. I don't think anyone can make such outfits. It is possible only by our own retailers.

That's why our own products are so much successful and well reputed today.

\subsection{Culture Specific Marketing Efforts}

According to the results of the focus group interviews, culture specific marketing efforts influence the purchase of local retail apparel brands in Bangladesh. Several factors shape culture specific marketing efforts, namely; after sales service, easiness of online transaction, convenient location, store atmosphere, availability of outlet, promoting cultural events, and local celebrity endorsement. The culture specific marketing factors can be visualized in Figure 2.

After sales service-Culture specific after sales service initiated by local retail apparel branded companies contributed to their popularities. This is evident by the following two responses of two Dhaka participants; a female and a male respectively.

[.....] For an example you buy a pant and somehow it requires little alteration, the local brands do that for free. This is not available in case of foreign brand. You can exchange or return if you do not like the item that you bought.

[..... Some of them are popular because you can return if you don't like an item but some you cannot. Thus, these are not popular and people don't buy from them.

Easiness of online transaction-Focus group interviews revealed that local retail apparel branded companies made online transactions easy for their customers considering that most of the consumers do not have access to credit cards. Thus, these companies allow cash payment as soon as the products are delivered to the customers. Please see the following statement of a male respondent from Dhaka.

[..... Not many people of our country have access to credit card and this has been capitalized by our local apparel manufacturers. You can order something online without payment and pay cash during the delivery of the item. This has increased the popularity of online shopping [.....]. Local apparel companies use social media, mostly Facebook for displaying their products and people can also call the seller and order but can pay after delivery. There is also provision of not accepting the order just by paying the shipping cost. It is so convenient and many people buy due to this [.....].

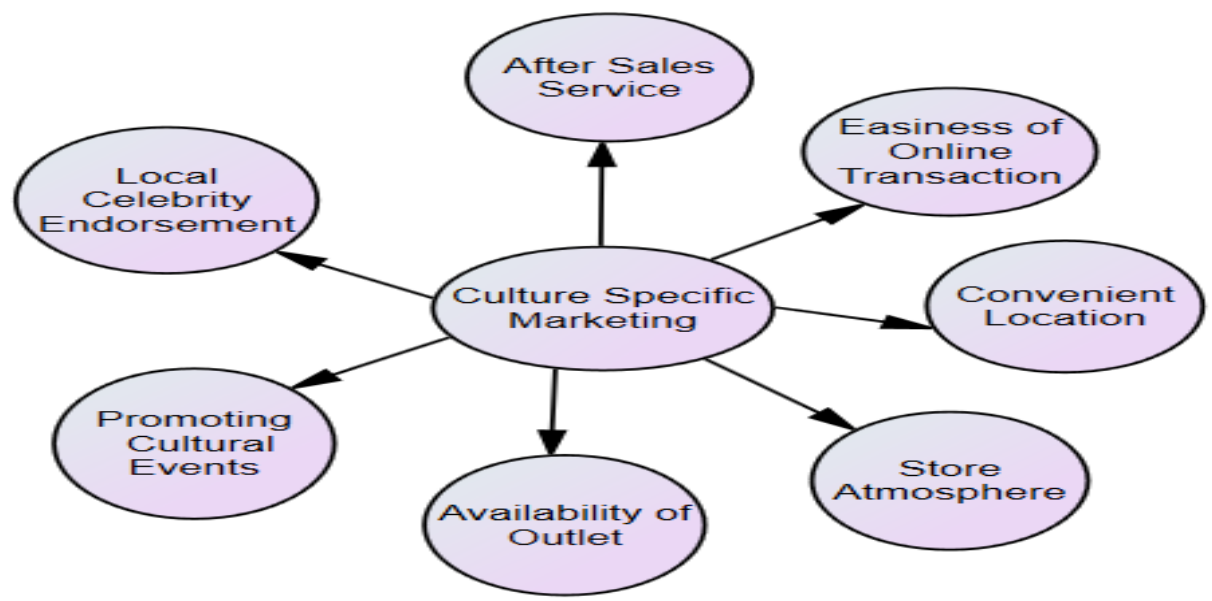

Figure 2. Culture specific marketing factors

Convenient location-Focus group interviews suggested that people buy from local retail stores due to their location. One of the male participants from Dhaka responded as follows.

[..... Dhaka city is the mostly populated city of the country. Think about the traffic jam. If you are out for one job and the day is over due to huge traffic. Thus, location is important. People try to avoid traffic. That is why stores are mostly located in the posh areas like Dhanmodi, Gulshan, Banani, Uttara etc. These days, local clothing retail stores actually located everywhere of the country so that it doesn't matter which part of the country that they live, but have access to these stores. If you have a store near you definitely you will buy from there $[\ldots . .$.$] .$ 
Store atmosphere-People buy local retail brands due to the store atmosphere as evidenced by the following statement of a male respondent from Chittagong.

[..... To me location and atmosphere are important factors. I cannot go to an overcrowded place to waste my whole day. Most of the retail brands are located in the posh areas of the country and the shopping atmosphere inside and outside stores is also good [.....]. That's why you see rich people also go for shopping in these stores.

Availability of outlet-The focus group interviews revealed that the people of the country buy locally made apparel due to the availability of the retail outlets. This can be supported by the response of a male participant from Dhaka.

It doesn't matter where you go, the local branded retail clothing stores are located everywhere. You can just get in and buy for you and your family members. Inventory is so rich in every store [......].

Promoting cultural events-Focus group interviews revealed that local branded retail stores promote cultural events of the country and produce outfits for every individual event. This can be evident by the following response of a female participant from Chittagong.

[.....] You cannot find a single cultural event when they do not produce to capture that particular event. Despite the social hierarchy all kinds of people buy clothing to match each particular cultural event. Imagine, my house maid was also asking for salary advance to buy clothing for her children because of Bangla new year [.....]. It doesn't matter who you are but each and every person of the country celebrate each individual event. This is how the different cultural events have been internalized among our people due to the availability of clothing during each event.

Local celebrity endorsement-This is another reason for the popularity of local retail apparel brands in Bangladesh. A male participant from Dhaka respond:

[.....] You will see the celebrity endorsement as soon as you proceed to a store. The local celebrities are used on TV advertisements and billboards [.....]. People are influenced to buy because of the endorsement of their liked celebrities. I think the high-income group people are not much influenced by this technique but the low-income group people really like their celebrities and so they buy [.....].

\subsection{Socio-Economic Factors}

The focus group interviews revealed that the local retail apparel brands in Bangladesh are popular due to influence of some socio-economic factors such as; increase of purchasing power of people, countrywide rapid expansion of tertiary academic institutions, family influence on purchasing local retail brands, change of behavioral pattern from buying tailored items to readymade items, and success of Bangladesh made garments outside the country. The socio-economic factors can be viewed in Figure 3.

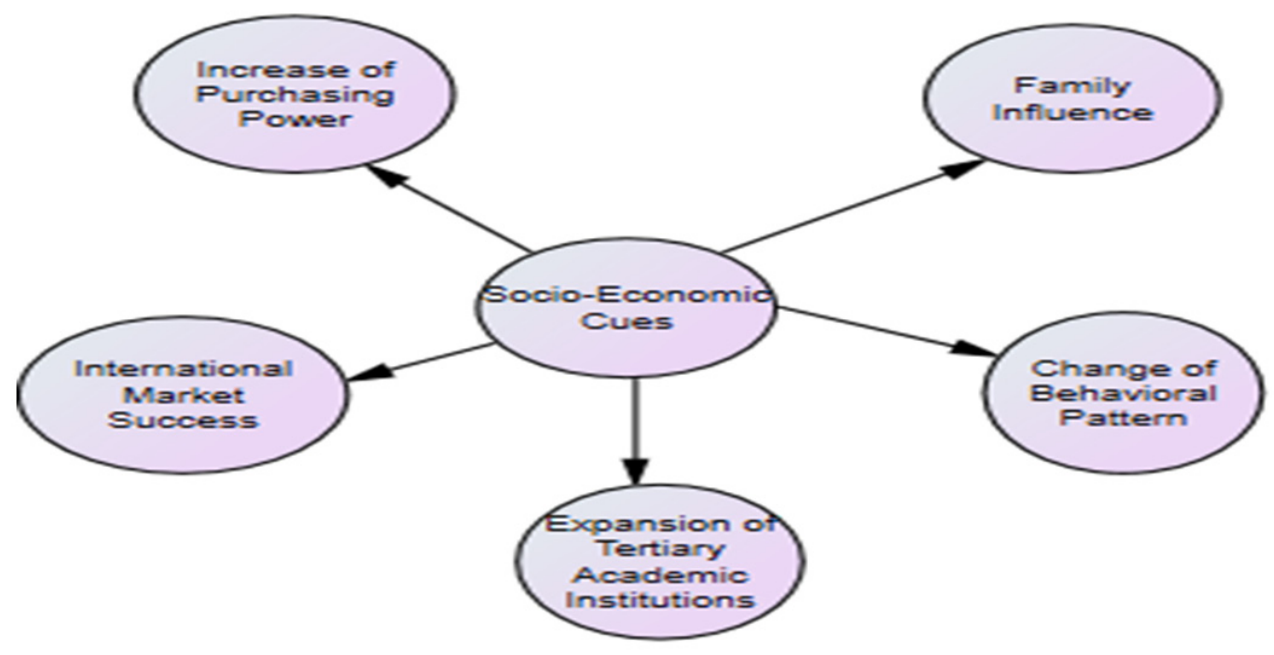

Figure 3. Socio-economic factors 
Increase of purchasing power-Bangladesh has witnessed enormous economic growth recently with resulting increased purchasing power of its people. Residents now buy more and from their own retail branded stores as supported by the following statement of a male respondent from Dhaka.

[..... People can buy more now due to the increase of purchasing power. Today, even a rikshaw puller makes TK30,000 a month. Can you imagine, a fresh university graduate starts with TK100,000 a month? This has enabled due to county's rapid economic growth. Private sector is growing like anything. Employment rate is eye catching. Don't you think people buy more if their income goes up? And they simply buy from local retail brands. That is why our local retail brands sell fast [.....].

Expansion of tertiary academic institution-The focus group interviews revealed that the expansion of tertiary academic institutions all over the country helped the growth of local retail apparel brands in Bangladesh. This can be witnessed by the response of a male participant from Dhaka.

[.....] If you see the recent trend of the increase of higher academic institutions in the country, it is extremely noticeable. There are about 100 private universities now operate and provide higher education. The number of public universities is also increasing. This means that, today, there is a huge number of students enrolled for higher education country wide. The younger generation need to keep themselves updated with the latest styles and fashions in order to be accepted by their peers. How do you think they do it? I am a university student and I know exactly how [.....]. The local retail apparel branded stores are the source of fashions of these university going students. The local retail stores are not much expensive and the students can effort to buy from there, and so, they have become so popular [....].

Family influence-Family influence drives Bangladesh people to buy from local retail stores as witnessed by the response of a female participant from Dhaka.

[.....] The elderly people take their children to the local retailers and buy from there. It has become a culture to buy from popular local retail brands. If you go to a certain local retail store, you will see the whole family is over there for shopping. Our people really enjoy shopping. When these children are grown up, they already know there shopping places [.....]. Thus, I would say family influence is there for the popularity of our own retail brands.

Change of behavioral pattern of people-The focus group interview revealed that local retail branded clothing stores are popular due to the changing behavioral patterns of people. Not many years ago, people brought fabric to the tailor to make their dresses. They offered their own designs during this process. Today, people resist this process as it is much complicated and time consuming. In addition, people are busier now due to high pressures in their workplaces and social life. This can be supported by a statement from a male participant from Dhaka.

[..... If you remember, we did not have access to much readymade retail stores when we were younger. We used to buy fabrics and go to tailor shop for making anything. It was a complex job. You had to give measurement, and then go for trial. You had to wait a longer period of time. And now, you just go and see which one fits on you and then buy. You save, time, hassle, and energy. You just buy the one that you like from the available one in the market. I would say this is a change in our behavioral pattern and the local companies could do that [.....]. That is why, people buy from local market.

Success of Bangladesh made garment in the international market — It has been revealed that Bangladesh people buy from local retail brands due to success of their export-oriented garment companies in the international market. This can be witnessed by the response of a male participant from Dhaka.

[..... We are one of the most successful garment exporters in the world. It doesn't matter where you go but if you buy a dress from the market, there is a 50/50 chance that the product is made in Bangladesh. When our product is so successful outside the country why then we buy imported clothing. That's why our people buy from the local market.

\section{Discussion}

The results of the study affirm that the success of locally produced retail apparel clothing in Bangladesh is greatly influenced by the intrinsic and extrinsic factors such as product's quality, price, and retailers' reputation and brand name. The local retailers do not comprise with quality in any given situation as they produce items to sell in the local market. These products were praised by the respondents of this study due to their durability, stitching, and well finishing. It hints local retail clothing sellers in Bangladesh to concentrate producing quality items should they look for success (Burton et al., 1998; Muruganantham \& Priyadharshini, 2017). The results further revealed that the local retail apparel clothing items are reasonably cheaper compared to the imported foreign brands which echoes the requirements of the local consumers as they incline to purchase quality products with low price. 
Keeping this in mind, it is recommended that the local retailers must make sure to produce quality apparel clothing items and price them lower than the imported branded items (Garretson et al., 2002; Beneke et al., 2013). The consumers in Bangladesh buy from the local retailers due to their image and reputation in the local markets. Over the years, the local retailers have displayed uncompromising attitude towards producing quality items along with competitive pricing decisions. The similar item made in Bangladesh are sold in a much higher price in branded stores operating locally and internationally. Moreover, the local retailers use the same technology and materials that of foreign brands but apply completely different and unique color combination and styles as they produce clothing items which help them building brand names and earning retailers' reputation and so able to attract the local consumers in a greater extent (Muruganantham \& Priyadharshini, 2017; Martenson, 2007). Considering the above situation, we therefore propose that the higher the presence of intrinsic and extrinsic factors, the greater the purchase of local retail apparel clothing in Bangladesh.

The results revealed that the people of Bangladesh purchase from the local retail apparel branded stores due to their adoption of culture specific marketing efforts. Since this kind of marketing efforts increase the sales, it is suggested that the local retail apparel branded stores in Bangladesh identify and design culture specific after sales service (free attire alteration, and return/exchange provision). It is also recommended that these companies continue accepting payment after delivery of the online ordered product for customers who do not have access to credit cards (Yang \& Young, 2009). The local retail apparel branded stores must also increase the number of outlets in conveniently located areas and, design pleasant and hassle-free outlets for attracting customers from all segments (Paulins \& Geistfeld, 2003; Michon et al., 2008). It is important that retailers continue to promote and produce event specific attires cultural events. Further, since local celebrity endorsement is positively related to increased sales, the local retail branded stores should consider using celebrity endorsers as part of their promotional efforts (Jansson \& Power, 2010). Considering the results of the focus group interviews it is certain that the local retail apparel branded stores in Bangladesh are successful in terms of their sales due to their adoption of culture specific marketing efforts. We therefore propose that the higher the culture specific marketing efforts adopted by the local retail apparel branded companies in Bangladesh, the greater the purchase.

It has been revealed from the results of the study that the socioeconomic development of the country is related to the success of local retail apparel branded companies in Bangladesh. Over the years, Bangladesh has witnessed a tremendous but constant economic growth that contributed to the purchasing power of the people (Bangladesh GDP Growth, 2018). This in turn increased the number of customers that looked for varieties of fashion-oriented apparel products and helped the local retail apparel branded companies grow. Results further suggested that the country has experienced a huge increase in the number of tertiary education institutions (Zebal \& Goodwin, 2012). Most of the one hundred private universities and thirty-five other public universities in operation are located in urban areas. Collegians attending these institutions create additional demand for fashion-oriented but reasonably priced apparel garments. Since the local retail apparel branded companies meet the attire requirements of these collegians, the popularity and sales of these companies are increased. Thus, it is recommended that the local retail apparel branded companies in Bangladesh target their marketing initiatives to the university students to maintain demand. As noted in the interviews, apparel products purchased in Bangladesh are heavily influenced by the family unit, the parents in particular. It was shown as a practice that the whole family together visit stores for shopping. Thus, in order to increase sales and generate more customers, it is recommended that the local retail apparel branded companies in Bangladesh initiate their marketing efforts towards these household units. It is to be noted from the results that there has been a change in behavioral pattern of the consumers during the purchasing process of apparel brands. Today, buying fabrics and outsourcing tailoring service is deemed complex and time consuming. Thus, they look for readymade garments available in the stores. Since, the local companies offer all kinds of readymade garments ranging from regular fit to slim fit, the consumers find their appropriate attires matching with their body structure from these stores. This convenience of location and breadth of choice helps the local retail apparel companies increase their sales. Further, Bangladesh made garments are extremely successful in the international market as the country makes garments for well-known branded apparel companies worldwide. Thus, considering above situations and results of the study, we propose that the socioeconomic factors in Bangladesh have a significant relationship with the purchase of local retail apparel branded products in the country.

\section{Implications and Future Research Direction}

The study identifies the key factors that influence the success of locally produced retail apparel clothing in Bangladesh. Since intrinsic and extrinsic factors such as quality, price, retailer's reputation and brand name have been identified as critical factors to be successful, the manufacturers and managers in Bangladesh now can implement these factors before, after and during production which in turn will heavily attract consumers towards 
the purchase of these products. Furthermore, the produced products will be durable, wells stitched, and well finished as soon as quality guidelines resulted in this study are followed. The combination of quality, unique color combinations, styles, and reasonable price will enhance the improvement of retailers' reputation and increase of brand name. This will give more weigh on the locally produced goods and the consumers will prefer locally produced items more than the expensive imported items. Culture specific marketing efforts identified in this study can be adopted and implemented by the locally produced retail apparel manufacturers and managers in Bangladesh Free alteration of items purchased from locally produced retail stores will provide a competitive edge over imported foreign goods since it is one of the key success requirements. Furthermore, many shoppers yet to obtain credit card facilities and the locally produced retail stores will be beneficial and advantageous over foreign branded stores by accepting cash payment after delivery of the sold items. Operating stores in convenient locations, designing and facilitating pleasant and hassle-free atmosphere can improve business as long as the locally produced retail stores sell quality products. Above all, producing products considering each cultural event lock the consumers in Bangladesh towards the purchase of locally produced clothing items. The local companies seeking success therefore, can learn a lesson from this study and research their consumers in producing event centered attires. Furthermore, the managers of locally produced retail stores can now invest more on producing event specific items since it generates cash flows and bring ultimate success. The manufactures and managers of the locally produced retail apparel companies in Bangladesh can be heavily benefitted by the socio-economic factors identified in this study. Having appropriate watch on the purchasing power trend of consumers along with researching on family influence and behavioral pattern will help the local companies designing, producing, and offering expected competitive items towards success and business viability. The findings of the study provide lesson for the mangers on how and what types of attire to produce should they be successful and competitive. Hence, the managers of the local retail apparel branded stores can get the benefit of this factor by learning the wearing and stylish behavior of collegians since the country is experiencing huge expansion in tertiary education.

Since the study identifies the key factors (strategies and tactics) that motivate consumer purchase of locally produced retail apparel clothing, in turn, this will, boost the country's economy with the growth of local companies. Adopting these identified factors by the local companies in their offerings will result in further increased demand. Moreover, if the size of the home demand is large then it is probable to see aggressive investment in the firm leading to social development, women empowerment and poverty alleviation of the country. Contrary, if the company lacks business then it is probable that the investors of the firm would be unmotivated to invest and resulting in reduced productivity and technological development. Furthermore, the key success factors identified in this study can be used as guidelines for the local retail clothing manufactures in developing countries that suffer from business competition with the imported foreign branded clothing stores. The study also enriches the consumer behavior literature by voiding the gap and contributing to the identification of local retail apparel clothing success factors. This will provide supporting foundation to the academics designing further studies that include local retail apparel clothing companies both in developed and developing countries.

Considering the purpose of the study, this paper investigates and identifies the key success factors of local retail apparel clothing brands in Bangladesh. The future study may include all types of local retail apparel branded items and see if the results are aligned with the current one. This paper is exploratory in nature that used focus group methods for data collection. Future studies may be quantitative, drawing bigger sample from both developed and developing country markets in order to make comparative analysis of the success factors between the two settings.

\section{References}

Agbonifoh, B. A., \& Elimimian, J. U. (1999). Attitudes of developing countries towards 'country-of-origin' products in an era of multiple brands. Journal of International Consumer Marketing, 11(4), 97-116. https://doi.org/10.1300/J046v11n04_06

Ahmed, Z. U., Al-Kwifi, O. S., Saiti, B., \& Othman, N. B. (2014). Consumer behavior dynamics of Chinese minorities. Journal of Technology Management in China, 9(1), 6-23. https://doi.org/10.1108/JTMC-10-2013-0038

Al-Kwifi, O. S., \& Ahmed, Z. U. (2014). Chalco: building a global brand while passing industry crisis. Journal of Technology Management in China, 9(1), 75-90. https://doi.org/10.1108/JTMC-10-2013-0037

Anchor, J. R., \& Kourilova, T. (2009). Consumer perceptions of own brands: international differences. Journal of Consumer Marketing, 26(6), 437-449. https://doi.org/10.1108/07363760910988256

Barbour, R. (2007). Doing focus groups. London: Sage. https://doi.org/10.4135/9781849208956

Batra, R., \& Sinha, I. (2000). Consumer-level factors moderating the success of private label brands. Journal of 
Retailing, 76(2), 175-191. https://doi.org/10.1016/S0022-4359(00)00027-0

Batra, R., Venkatram, R., Alden, D. L., Steenkamp, J. E. M., \& Ramachander, S. (2000). Effects of brand local and nonlocal origin on consumer attitudes in developing countries. Journal of Consumer Psychology, 9(2), 83-85. https://doi.org/10.1207/S15327663JCP0902_3

Bellizzi, J. A., Hamilton, J. R., Krueckeberg, H. F., \& Martin, W. S. (1981). Consumer perceptions of national, private, and generic brands. Journal of Retailing, 57(4), 56-70.

Beneke, J., Flynn, R., Greig, T., \& Mukaiwa, M. (2013). The influence of perceived product quality, relative price and risk on customer value and willingness to buy: a study of private label merchandise. The Journal of Product and Brand Management, 22(3), 218-228. https://doi.org/10.1108/JPBM-02-2013-0262

Burton, S., Lichtenstein, D. R., Netemeyer, R. G., \& Garretson, J. A. (1998). A scale for measuring attitude toward private label products and an examination of its psychological and behavioural correlates. Academy of Marketing Science Journal, 26(4), 293-306. https://doi.org/10.1177/0092070398264003

Carson, D., Gilmore, A., Perry, C., \& Gronhaug, K. (2001). Qualitative Marketing Research. London: Sage. https://doi.org/10.4135/9781849209625

Chaniotakis, I. E., Lymperopoulos, C., \& Soureli, M. (2010). Consumers' intentions of buying gown-label premium food products. The Journal of Product and Brand Management, 19(5), 327-334. https://doi.org/10.1108/10610421011068568

Chen, C. H., \& Chang, Y. W. (2001). The Impact of Brand Associations on Brand Equity. Journal of Management, 18(1), 3-14.

Chrysochou, P., Krystsllis, A., \& Giraud, G. (2012). Quality assurance labels as drivers of customer loyalty in the case of traditional food products. Food Quality and Preference, 25(2), 156-162. https://doi.org/10.1016/j.foodqual.2012.02.013

Dabholkar, P. A., Thorpe, D. I., \& Rentz, J. O. (1996). A measure of service quality for retail stores: scale development and validation. Journal of the Academy of Marketing Science, 24(1), 3-16. https://doi.org/10.1007/BF02893933

Dodds, W. B., Monroe, K. B., \& Grewal, D. (1991). Effects of Price, Brand, and Store Information on Buyers' Product Evaluation. Journal of Marketing Research, 28, 307-319. https://doi.org/10.1177/002224379102800305

Doody, O., Slevin, E., \& Taggart, L. (2013). Focus group interviews part 3: Analysis. British Journal of Nursing, 22(5), 266-269.

Enneking, U., Neumann, C., \& Henneber, S. (2007). How important intrinsic and extrinsic product attributes affect purchase decision. Food Quality and Preference, 17(1), 133-138. https://doi.org/10.1016/j.foodqual.2005.09.008

Fandos, C., \& Flavian, C. (2006). Intrinsic and extrinsic quality attributes, loyalty and buying intention: an analysis for a PDO product. British Food Journal, 108(8), 646-662. https://doi.org/10.1108/00070700610682337

Garretson, J. A., Fisher, D., \& Burton, S. (2002). Antecedents of private label attitude and national brand promotion attitude: similarities and differences. Journal of Retailing, 78(2), 91-99. https://doi.org/10.1016/S0022-4359(02)00071-4

Ger, G., Belk, R. W., \& Lascu, D. N. (1993). The development of consumer desire in marketing and developing economies: the cases of Romania and Turkey. In L. McAlister \& M. L. Rothschild (Eds.), Advances in Consumer Research (vol. 20, pp. 102-107). Association for Consumer Research, Provo, Utah.

Glynn, M. S., \& Chen, S. (2009). Consumer-factors moderating private label brand success: further empirical results. International Journal of Retail and Distribution Management, 37(11), 896-914. https://doi.org/10.1108/09590550910999343

Goodwin, C., Mayo, M., \& Hill, R. P. (1997). Salesperson Response to Loos of A Major Account: A Qualitative Analysis. Journal of Business Research, 40(2), 167-180. https://doi.org/10.1016/S0148-2963(97)00018-0

Ha, Y., Kwon, W.-S., \& Lennon, S. J. (2007). Online visual merchandising (VMD) of apparel web sites. JFMM, 11(4), 477-493. https://doi.org/10.1108/13612020710824553

Halim, W. Z. W., \& Hamed, A. B. (2005). Consumer purchase Intention at traditional restaurant and fast food 
restaurant. Consumer Behavior.

Herche, J. (1992). A note on the predictive validity of the CETSCALE. Journal of the Academy of Marketing Science, 20(3), 261-264. https://doi.org/10.1007/BF02723413

Jansson, J., \& Power, D. (2010). Fashioning a Global City: Global City Brand Channels in the Fashion and Design Industries. Journal of Regional Studies Association, 44(7), 889-904. https://doi.org/10.1080/00343400903401584

Kirmani, A., \& Baumgartner, H. (2000). Reference points used in quality and value judgments. Marketing Letters, 11(4), 229-234. https://doi.org/10.1023/A:1008129011202

Kottak, C. P. (1990). Prime Time Society. Wadsworth, Belmont, CA.

Krueger, R. A. (1994). Focus Groups: A Practical Guide for Applied Research. Thousand Oaks, CA: Sage.

Krueger, R. A., \& Casey, M. A. (2000). Focus Groups: A Practical Guide for Applied Research (3rd ed.). Thousand Oaks, CA: Sage Publications.

Lafferty, B. A., \& Goldsmith, R. E. (1999). Corporate Credibility's Role in Consumers' Attitudes and Purchase Intentions When a High Versus a Low Credibility Endorser Is Used in the Ad. Journal of Business Research, 44, 109-116. https://doi.org/10.1016/S0148-2963(98)00002-2

Lee, M., \& Lou, Y.-C. (2011). Consumer Reliance on Intrinsic and Extrinsic Factors in Product Evaluations: A Conjoint Approach. Journal of Applied Business Research, 12(1), 21-29. https://doi.org/10.19030/jabr.v12i1.5833

Li, Z., Fu, S., \& Murray, L. W. (1997). Country and product images: the perceptions of consumers in the people's republic of China. Journal of International Consumer Marketing, 10(2), 115-139. https://doi.org/10.1300/J046v10n01_07

Lin, C., Marshall, D., \& Dawson, J. (2009). Consumer attitudes towards a European retailer's private brand food products: an integrated model of Taiwanese consumers. Journal of Marketing Management, 25(9), 875-891. https://doi.org/10.1362/026725709X479273

Martenson, R. (2007). Corporate brand image, satisfaction and store loyalty. International Journal of Retail and Distribution Management, 35(7), 544-555. https://doi.org/10.1108/09590550710755921

Martin, P. Y., \& Turner, B. A. (1986). Grounded Theory and Organizational Research. The Journal of Applied Behavioural Science, 22(2), 141-157. https://doi.org/10.1177/002188638602200207

McCormick, H., \& Livett, C. (2012). Analysing the influence of the presentation of fashion garments on young consumers' online behavior. JFMM, 16(1), 21-41. https://doi.org/10.1108/13612021211203014

Michon, R., Yu, H., Smith, D., \& Chebat, J. C. (2008). The influence of mall environment on female fashion shoppers' value and behavior. JFMM, 12(4), 456-468. https://doi.org/10.1108/13612020810906128

Mujtaba, B. G. (2013). Negotiating with modern Chinese professionals: A review of cultural considerations and cyberspace communication. Journal of Technology Management in China, 8(3), 190-202. https://doi.org/10.1108/JTMC-07-2013-0031

Muruganantham, G., \& Priyadharshini, K. (2017). Antecedents and consequences of private brand purchase: A systematic review and a conceptual framework. International Journal of Retail \& Distribution Management, 45(6), 660-682. https://doi.org/10.1108/IJRDM-02-2016-0025

Netemeyer, R. G., Krishnan, B., Pullig, C., Wang, G., Yagci, M., Dean, D., ... Wirth, F. (2004). Developing and validating measures of facets of customer-based brand equity. Journal of Business Research, 57(2), 209-224. https://doi.org/10.1016/S0148-2963(01)00303-4

Nitisha. (2018). 5 factors that affect the economic growth of a country. Retrieved May 12, 2008, from http://www.economicdiscussion.net/economic-growth

Parasuraman, A., Zeithaml, V. A., \& Berry, L. L. (1988). SERVQUAL: a multiple-item scale for measuring customer perceptions of service quality. Journal of Retailing, 64, 12-40.

Paulins, V. A., \& Geistfeld, L. V. (2003). The effect of consumer perceptions of store attributes on apparel store preference. JFMM, 7(4), 371-385. https://doi.org/10.1108/13612020310496967

Piron, F. (2000). Consumers' perceptions of the country-of-origin effect on purchasing intentions of (in) conspicuous products. Journal of Consumer Marketing, 17(4), 308-321. 
https://doi.org/10.1108/07363760010335330

Rahman, H. Z. (2014). Urbanization in Bangladesh: Challenges and Priorities. The first BEF conference, June 21-22, Dhaka. Retrieved May 15, 2018, from http://www.pribd.org/upload/file/bef_paper/1414213688.pdf

Reynolds, T., \& Gutman, J. (1988). Laddering Theory, Method, Analysis and Interpretation. Journal of Advertising Research, 28(1), 11-31.

Richardson, C. A., \& Rabiee, F. (2001). A Question of Access - an exploration of the factors influencing the health of young males aged 15-19 living in Corby and their use of health care services. Health Education Journal, 60, 3-6. https://doi.org/10.1177/001789690106000102

Richardson, P. S., Dick, A. S., \& Jain, A. K. (1994). Extrinsic and intrinsic cue effects on perceptions of store brand quality. Journal of Marketing, 58(4), 28-36. https://doi.org/10.1177/002224299405800403

Ritchie, J., \& Spencer, L. (1994). Qualitative data analysis for applied policy research. In Analysing Qualitative Data (pp. 173-194, A Bryman and RG Burgess, editors). London: Routledge

Saiki, D. (2008). Featuring clothing and textile collections on-line. Aslib Proceedings, Emerald Group Publishing Limited. https://doi.org/10.1108/00012530810862446

Schiffman, L. G., \& Kanuk, L. L. (2000). Consumer Behavior (7th ed.). Printice Hall.

Sklair, L. (1994). The culture-ideology of consumerism in urban China: some findings from a survey in Shanghai. In C. J. Schultz II, R. W. Belk \& G. Ger (Eds.), Research in Consumer Behavior (vol. 7, pp. 259-292). JAL, Greenwich, CT.

Stewart, D. W., \& Shamdasani, P. N. (1990). Focus Groups: Theory and Practice. Thousand Oaks, CA: Sage.

Szybillo, G., \& Jacobya, J. (1974). Intrinsic versus extrinsic factors as determinants of perceived product quality. Journal of Applied Psychology, 59(1), 74-78. https://doi.org/10.1037/h0035796

Thomas, L., MacMillan, J., McColl, E., Hale, C., \& Bond, S. (1995) Comparison of focus group and individual interview methodology in examining patient satisfaction with nursing care. Social Sciences in Health, 1(4), 206-219.

Thomas, T., \& Carraher, C. E. (2014). A retail perspective on the shopping behavior, cultures and personalities for China, United Arab Emirates, Belgium, India, Germany and America. Journal of Technology Management in China, 9(3), 289-296. https://doi.org/10.1108/JTMC-08-2014-0050

Turner, B. A. (1981). Some Practical Aspects of Qualitative Data Analysis: One Way of Organising the Cognitive Processes Associated with The Generation of Grounded Theory. Quality and Quantity, 15(3), 225-245. https://doi.org/10.1007/BF00164639

Wang, C. L., \& Chen, Z. X. (2004). Consumer ethnocentrism and willingness to buy domestic products in a developing country setting: testing moderating effects. Journal of Consumer Marketing, 21(6), 391-400. https://doi.org/10.1108/07363760410558663

Wang, C. L., Chen, Z. X., Chan, A. K. K., \& Zheng, Z. C. (2000). The influence of hedonic values on consumer behaviors: an empirical investigation in China. Journal of Global Marketing, 14(1/2), 169-186. https://doi.org/10.1300/J042v14n01_09

Whitlark, D. B., Geurts, M. D., \& Swenson, M. J. (1993). New product forecasting with a purchase intention survey. Journal of Business Forecasting, 18-21.

World Bank. (2018). IMF: Bangladesh's economic growth is promising. Retrieved May 12, 2018, from https://www.dhakatribune.com/business/economy/2018/04/21/imf-bangladeshs-economic-growth-promisin g/

Wu, P. C., Yeh, G. Y. Y., \& Hsiao, C. R. (2011). The effect of store image and service quality on brand image and purchase intention for private label brands. Australasian Marketing Journal, 19(1), 30-39. https://doi.org/10.1016/j.ausmj.2010.11.001

Yang, K., \& Young, A. P. (2009). The effects of customized site features on internet apparel shopping. JFMM, 13(1), 128-139. https://doi.org/10.1108/13612020910939923

Zebal, M. A., \& Goodwin, D. R. (2012). Market Orientation and Performance in Private Universities. Marketing Intelligence and Planning, 30(3), 339-357. https://doi.org/10.1108/02634501211226302

Zeithaml, V. A. (1988). Consumer perceptions of price, quality, and value: a means-end model and synthesis of 
evidence. The Journal of Marketing, 52, 2-22. https://doi.org/10.1177/002224298805200302

\section{Copyrights}

Copyright for this article is retained by the author, with first publication rights granted to the journal.

This is an open-access article distributed under the terms and conditions of the Creative Commons Attribution license (http://creativecommons.org/licenses/by/4.0/). 